\title{
\begin{tabular}{lllllllllllllll}
$\mathrm{T}$ & $\mathrm{U}$ & $\mathrm{R}$ & $\mathrm{K}$ & $\mathrm{T}$ & $\mathrm{A}$ & $\mathrm{R}$ & $\mathrm{I}$ & $\mathrm{H}$ & $\mathrm{K}$ & $\mathrm{U}$ & $\mathrm{R}$ & $\mathrm{U}$ & $\mathrm{M}$ & $\mathrm{U}$ \\
\hline
\end{tabular} \\ BELLETEN

\section{HITITÇE ÇIVI YAZILI BELGELERE GÖRE ÇOBAN}

\section{TURGUT Yí̆İT*}

M.Ö. II. binylda Anadolu'da çok önemli bir siyasal güç olarak ortaya çıkan Hititler, bu dönem dünyasının en çok dikkati çeken kültürlerinden birini de ortaya koymuşlardır. Hitit Devleti'nin ilk kez ortaya çıktığı yer, Hitit kültürünün izlerine bugün en yoğun olarak rastlanan bölge olan Kızılırmak'ın çizdiği geniş kavsin içinde kalan topraklardır. Bu merkez alandan hareketle Hititler, Anadolu'nun her yönünde siyasal ve askeri faaliyetlere girişmişler, devletin sınırlarını bu yönlerde genişletmişlerdir. M.Ö. XII. yüzyıl başlarındaki Hitit Devleti'nin yıkılışına dek Anadolu'nun pek çok yerinde ve ondan sonra biraz daha değişik kimliklerle Anadolu'nun güneyi ve güneydoğusunda Hititler'in izlerini takip edebilmekteyiz.

Avcllık ve toplayıcılık ekonomisinden sonra ilk üretimcilik evresini temsil eden neolitik çağdan itibaren Anadolu'da tüm tarih boyunca geçim kaynağının temelini tarım ve hayvancılık oluşturmuştur. Arkeolojik kazıların sonuçlanı ile Anadolu topraklarında tarımın ve hayvancılığın gelişimi izlenebilmektedir. Yazının bu topraklarda kullanılmaya başlanması ile birlikte de yine geçim kaynağının temelini oluşturan tarım ve hayvancılığın Anadolu kültüründeki yerini yazılı kaynaklar vasıtasıyla öğrenebilmekteyiz.

Hititçe çivi yazılı belgelerde, insanların çeşitli ürünlerinden ve gücünden faydalandıkları evcil hayvanların isimleri geçer: "UDU=koyun",

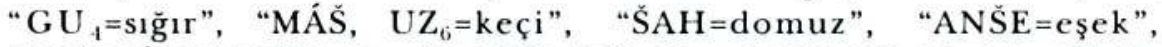
"ANŠE.GİR.NUN.NA= katur", "ANŠE.KUR.RA=at", "UR, UR.GI ${ }_{7}=k o ̈ p e k " 1 . ~ B u$

* A.Ü. DTCF, Eskiçağ Tarihi Anabilim Dah.

'Boğazkōy metinlerinde geçen hayvan isimleri için bak. H. Ertem, Boğazköy Metinlerine göre Hititler Devri Anadolu'sunun Faunası, Ankara 1965. 
hayvanların farklı türleriyle ve cinsleriyle ilgili olarak metinlerde sayısız kayıt vardır. Hayvancılığın Hitit ekonomisinde önemli yer tutması dolayısıla hayvanların Hititçe belgelerde epeyce anıldığına şahit oluruz. Ancak sadece ekonomik değerleri dolayısıyla değil, tanrıya sunulan kurban hayvanları olmalarından dolayı dinsel içerikli belgelerde ve bayram törenlerini konu alan belgelerde de çok sık hayvan isimleri yer alır.

Tüm Anadolulu toplumların yaşantısında olduğu gibi hayvancılığın önemli bir yer tuttuğu Hititler'den bize ulaşan çivi yazılı belgelerde, hayvanlan sevk ve idare eden, hayvanların bakımından beslenmesine ve onlardan elde edilen ürünlerin ortaya konmasına dek hayvancılıkla ilgili işleri yürüten çobanlarla ilgili kayıtlara rastlanmaktadır. Hitit ekonomisinde tarımdan sonra en önemli yeri hayvancılık işgal etmesine rağmen, çobanlıkla ilgili kaytlar Hititçe çivi yazılı belgelerde sınırlı saydadır. Mevcut kayıtların hepsinden de Hitit kültüründe çoban ve çobanlık üzerine bilgiler edinmek mümkün değildir. Hititçe çivi yazılı belgelerde çobanlıkla ilgili sözcük ve terimler hep sumerogram değerleri ile yer alırken, Hititçe olmak üzere çoban karş1lığı sözcük bir kez tespit edilebilmektedir ${ }^{2}$. Çobanlıkla ilgili sözcük ve terimlere kanunlardan fermanlara, antlaşmalardan dinsel içerikli metinlere dek farklı içerikli belgelerde rastlanıyorken, aşağıda ele alacağımız üzere çobanlık Hitit kültüründe farklı ortamlarda karşımıza çıkmaktadır.

LúSIPA.UDU ve LÚSIPA.GU 'nun geçtiği metinler incelendiğinde, bu unvanları taşıyan kişilerin doğrudan doğruya bu sumerogramların sahip olduğu anlamla ilgili işler, yani çobanlık ya da değişik ortamlarda bununla bağıntılı işler yaptukları anlaşılmaktadır. Koyun çobanı ve sığır çobanı anla-

${ }^{2}$ Hititçe çivi yazılı belgelerde tespit edilebilen çoban karşılı̆̆ı sõzcük "weštara"dır . Bunun yanı sıra, ilerleyen saturlarda bazılarının üzerinde duracağımız çobanlıkla ilgili sumerogram değerleri ile metinlerde yer alan sōzcük ve terimler topluca şōyledir: "LÛ́SIPA=çoban", "LÚSIPA.UDU=koyun çobanı", "LÚ SIPA.GU "LUU MÁŠ.GAL=keçi çobanı", "LỨŠH, LÚSIPA.Š̉AH=domuz çobanı", "UGULA LÚ.MEŚSIPA=çobanların başı", "GAL LÚMEŚSIPA= çobanların büyüğŭü, "LUU NA.KAD=çoban", "UGULA LÚ.MES NA.KAD=çobanların bașı", "GAL NA.KAD=çobanların büyüğū". Ayrıca "LÚ.MEŚŚE.KIN.KUD" da hayvanlarla ilgilendikleri tespit edilen "hasat iş̧ileri"dir. "Lú lapanalli" de Luwice "çoban" anlamındadır. Bunlar için bak. F.P.Daddi, Mestieri, professioni e dignita nelI'Anatolia ittita, Roma 1982. Bu eserde KBo I-XXVI, KUB I-L ve ABoT'deki sõz konusu sōzcūk ve terimlerin geçtiği metin yerleri verilmektedir. Daha sonra yayınlamış olan metinlerde de bu terim ve sōzcüklerin geçtikleri yerler gõzden geçirilmiş ve Hititler'de çobanlık konusunda bilgi elde edilebilenlere çalışmamızda değinilmiştir. Ayrıca Hitit kültüründe çobanlık için bak. G.Beckman, "Herding and Herdsmen in Hittite Culture," Documentum Asiae Minoris Antiquae, Fs. für H.Otten, Wiesbaden 1988, s.33 vd. 
mındaki bu terimler ferman, antlaşma, mektup, talimatname gibi çok farklı metin türlerinde karşımıza çıkmaktadır.

Tiliuralılar'la yapılan bir antlaşmada sığır çobanlanı ve koyun çobanları geçer $^{3}$. Hitit kralı III.Hattušili zamanına ait olup sınır şehri Tiliura'nın ${ }^{4}$ Kaškalar'la olan ilişkilerinin kontrol altına alınmasının amaçlandığı bu antlaşmada "sı̆ı̆ çobanları, koyun çobanları ve çiftçiler"in Kaška halkıyla birlikte hareket etmeleri engellenmek istenmektedir ${ }^{5}$. Aksi tutumda, yani Kaškalar'la kim anlaşırsa tutuklanacakur. Metinde bu ifadelerden hemen önceki satırlarda da Kaška'dan alınan kölelerin şehre sokulmayacağı, eğer sokulursa suç işlenmiş olunacağı belirtilmektedir. Metnin tamamına bakıldığında da yine Tiliura halkının Kaškalar'la olan ilişkilerine getirilen kısıtlamalara ve yasaklamalara tanık oluruz. Kaškalar'ın Orta Karadeniz bölgesinde bulundukları ${ }^{6}$ dikkate alınırsa, Kaškalar'la sınır şehri olduğu bilinen Tiliura'nın Hitit merkez alanının kuzeydoğusunda olduğu kabul edilmelidir. Sığır çobanları, koyun çobanları ve çiftçiler burada sözcüklerin anlamına uygun olarak kırsal kesimde yaşayan, iş gören gruplar olmalıdır. Şüphesiz bunlardan Kaškalar'a yakın yaşayanlar (ki bu bölge Kaška bölgesidir) bir şekilde onlarla ilişkide bulunuyor, belki alışveriş yapıyor veya karşılıklı çıkarları doğrultusunda birlikte hareket ediyorlardı. Nitekim aşağıda ele alacağımız bir metinde koyun çobanlarının Kaškalar'a yardım ettiklerini (askeri yardım) göreceğiz. Bir sınır şehriyle olan söz konusu antlaşma ile bu durum kesinlikle önlenmek istenmektedir. Kaškalar'ın yarı göçebe bir yaşam tarzı sürmeleri dolayısıyla hayvancılı̆ı̆ onlanın da geçimlerinde önemli bir yer işgal ettiği, Kaška toplumunda çobanlığın önemli bir yeri olduğu da düşünülebilir. Söz konusu sığır çobanları, koyun çobanları ve çiftçiler kırsal kesimde yaşıyor ve Tiliura şehrine idari, ekonomik vs. açılardan bağlı; belki de doğrudan burada oturuyor ve bu şehrin otoritesi altunda bulunuyor olmalıdırlar.

Kaškalar'la bir antlaşma metninde sığır çobanı ve koyun çobanı yine asıl anlamlarıyla uyumlu olarak geçerler ${ }^{7}$. Burada bu sözcükler , çobanın yaptı̆̆

${ }^{3}$ KUB XXI 29 III 44.

${ }^{4}$ Tiliura şehri için bak. G.F. del Monte- J. Tischler, Die Orts-und Gewassernamen der Hethitischen Texte, RGTC 6, Wiesbaden 1978, s.421 vd.

${ }^{5}$ KUB XXI 29 III 44-48. Bu metnin ilgili saturlan için bak. J.Garstang-O.R.Gurney, The Geography of the Hitcite Empire, London 1959, s.120; E.von Schuler, Die Kaskaer.Ein Beitrag zur Ethnographie des alten Kleinasien, Berlin 1965, s.147.

"A.M.Dinçol-J.Yakar, "Nerik Şehrinin Yeri Hakkında," Belleten 38/152(1974), s.564.

${ }^{7}$ KUB XXVI 19 Vs.II 22,24,36. Metnin ilgili yerleri için bak. Von Schuler, Die Kaskaer. s.131. 
asıl iş olan otlatmak fiili ${ }^{8}$ ile birlikte geçerler. Öyle anlaşılıyor ki bu antlaşma ile yapılan düzenlemeler arasında sığır ve koyun çobanları, bunların hayvan otlatmaları, onlara olan saldırılar, tazminat vs. yer almaktadır.

II.Muršili tarafından yazdırıimış olan Šuppiluliuma'nın icraatının anlatıldığı bir başka metinde, onun Kaškalar üzerine olan seferine değinilen

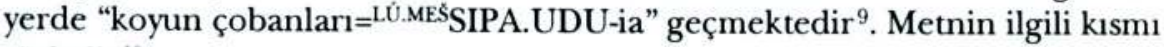
şöyledir ${ }^{10}$ :

“Babam tekrar Šamuha'dan hareket etti. Düşmanların tümü düşman tarafından yakılıp yıkılmış ülkedeydi. .... ve koyun çobanları yardıma geldi. Babam onlara bir tuzak kurdu ve Kaškalar'ı vurdu. Yardıma gelmiş olanları da vurdu; öyle ki Kaškalı askerler ve yardımcı askerler yığınla öldüler. Fakat onun aldığı tutsak sayısızdı".

Bu metinde konu Šuppiluliuma'nın Šamuha şehrinden hareketle Hitit ülkesinin kuzeydoğusunda yaptığı seferlerdir. Kralın asıl hedefi "Hayašalı düşman"dır"1. Ancak sefer sırasında Hayašalılar'la değil, "Kaškalı düşman"la karşılaşılmıştır ${ }^{12}$. Onlarla savaşılmış, çok sayıda düşman öldürülmüş ve bir kısmı esir alınmışur ${ }^{13}$. Yukanda verdiğimiz pasaj ise bundan sonrasını anlaur. Šuppiluliuma yeniden Šamuha'dan hareket etmiş, yine Kaškalar'la savaşmış ${ }^{14}$, ancak bu defa yardıma koyun çobanları ve metinde okunamayan kısımda bulunan bir grup daha, büyük ihtimalle sığır çobanları, gelmişlerdir. Metinde daha sonra "Kaškalı askerler" (ÉRINMEš Ka-aš-ka-aš) ve "yardımcı askerler" (ÉRIN $\left.{ }^{\text {MEŚs }} N[A-R A-R I]\right)$ ifadelerinin yer alması ilginçtir. Burada geçen yardımcı askerler, belgede ilgili satırlar dikkate alındığında üç satır önce geçen yukarıda bahsettiğimiz koyun çobanları ve adı okunamayan diğer grup olmalıdır. Sadece söz konusu ifadelere bakarak koyun çobanlarının düzenli bir askeri kuvvet niteliğinde burada anılmış olduğunu söyleyeme-

${ }^{8}$ wešiyaš "otlatmak". Bak. J.Friedrich, Hethitisches Wörterbuch, Heidelberg 1952, s.253.

${ }^{9}$ KUB XIX 11114.

${ }^{10}$ KUB XIX 11 I 11-18. Metnin ilgili saturları için bak. H.G.Güterbock, "The deeds of Suppiluliuma as told by his Son Mursili II," JCS 10/2(1956), s.63.

${ }^{11} \mathrm{KBo}$ XIX $11 \mathrm{I} 3$.

12 KBo XIX 11 I 6.

${ }^{13} \mathrm{KBo}$ XIX 11 I $7-10$.

14 Kaškalarla savaşılan Kaškalar'ın yakıp yıktıkları metinde adı verilmeyen yer, Śamuha'dan hareketle ulaşıldığına göre Śamuha'nın da içinde bulunduğu Yukarı Ülke'de bir yer olmalıdır. Von Schuler, Die Kaskaer, s.10'da aynı görüşü öne sürer. 
yiz $^{15}$. Herhalde kastedilen doğrudan asker olmamakla beraber kırsal alanda yaşayan ve kendi işiyle meşgul olan bazı grupların Kaškalar'la olan mücadelede taraf olmak durumunda kalmış olmalarıdır. Kırsal alanda yaşayanların kendi güvenlikleri açısından bu bölgede çok etkili olan Kaškalar'dan yana tavır almaları beklenebilir. Belki de sözü geçen koyun çobanları ve adı okunamayan diğer grup, Kaškalar'la aynı etnik kökenlidir. Yani Kaškalı savaş̧̧ıların haricinde onlara yardıma gelen Kaškalı ya da onlarla birlikte hareket eden başka gruplar olabilir. Şu da gözden uzak tutulmamalıdır ki, yukarıda da belirttiğimiz gibi yarı göçebe bir yaşam tarzına sahip olan ve hayvancılığın, dolayısıyla çobanlığın günlük yaşamlarında önemli bir yer tutuyor olması gereken Kaškalar, Hititçe çivi yazılı belgelerde savaşçı özellikleriyle ortaya çıkmaktadırlar.

Başkentin dışındaki bir üst düzey görevliden krala gönderilen mektupta ${ }^{16}$ yine koyun çobanları ve sığır çobanları kırsal alandaki asıl işlevleriyle yer alırlar. Mektupta üst düzey görevlinin düşmanın kendi bölgesine sızdığından bahsettiği anlaşılıyor. Koyun çobanları ve sığır çobanlarının yalnız bırakılmamasından söz edilmesi ${ }^{17}$, bunların düşmanın varlığı dolayısıyla serbest bırakılmadıklarını akla getirmektedir. Aksi halde hayvanlar düşmanın eline geçebilirdi.

Bir HAZANNU talimatı metninde ${ }^{18}$ geçen sığır çobanı ve koyun çobanı sıfatları ile anılanlar, ilerleyen saturlarda bahsedeceğimiz gibi benzer sıfatları taşıdıkları halde doğrudan çobanlık yapmayanların aksine, yine çoban sözcüğünün asıl anlamında, yani çobanlık yapan kişilerle ilgili olmalıdır ${ }^{19}$. Ancak bu konuda kesin bir şey söylenemez. Zira kırık olması dolayısıyla metin eksik olduğu için tam bir anlam çıkarmak zordur. Şehir kapılarında alınması gereken tedbirlerle ilgili olan söz konusu metin ${ }^{20}$ her ne kadar açıkça bir şey-

${ }^{15}$ Ancak burada ileride üzerinde duracağımız, asıl anlamı "çobanların büyüğü" olan GAL NA.KAD unvanını taşıyan üst düzey askeri görevlilerin Hititçe metinlerde geçtiği, her ne kadar doğrudan bağlant kurmak mümkün değilse de haturlanmalıdır.

${ }_{16} \mathrm{ABoT} 60$. Bu metin için bak. E.Laroche, "Lettre d'un prefet au roi hittite," $R H A$ $67(1960)$, s.8 vd. Orta Hitit dönemine tarihlenen bu mektubu gönderen, krala karşı sorumlu olan bir üst düzey taşra yōneticisi olmalıdır.

${ }^{17} \mathrm{ABoT} 60 \mathrm{Vs} 12$

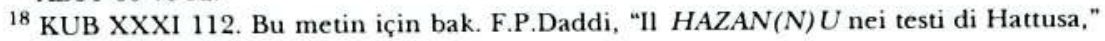
Or.An. 14(1975), s.106vd.

${ }^{19}$ KUB XXXI 11210.

${ }^{20}$ Beckman, Fs. Otten, s.41 ve dn.59. 
ler anlatmaktan uzak olsa da kırsal alanda işini yapmakta olan çobanın kentle de olan ilgisini göstermesi açısından göz önünde tutulabilir.

Yine bir mahkeme tutanağında, adı da verilen bir sığır çobanından bahsedilir ${ }^{21}$. Adı geçen "Huhhu"22 tutanağa konu olan davada olayla ilgili olarak yer alan sıradan bir sığır çobanıdır. Mahkeme konusu da zaten sığırlarla ilgilidir. Çoban ve çobanlığın Hitit kültüründeki yerine dair herhangi bir bilgi kazandırmamakla beraber sıradan bir sığır çobanının adına rastlanılan tek örnek olması açısından ilginçtir.

Hitit Kanunlarında çoban iki ayrı maddede açıkça görülür. Ancak bu iki kanun maddesi de benzer içeriğe sahiptirler ${ }^{23}$.

35.madde şöyledir ${ }^{24}$ :

"Eğer özgür bir kadını bir ${ }^{\mathrm{LU}} \mathrm{AGRIG}$ ya da bir çoban $\left({ }^{\mathrm{LU}} \mathrm{SIPA}\right)$ kaçırırsa, ve onun için başlık ödemezse, o zaman o(kadın) üçüncü yılda köle olur"

175. madde de benzer ifadeler içermektedir. Ancak burada öncekinden farklı olarak LÚAGRIG veya koyun çobanıyla(LÚSIPA.UDU) bir özgür kadın evlenirse kadının iki ya da dört yıl içinde köle olacağı vurgulanır ${ }^{25}$.

Hitit kanunlarındaki evlilik dolayısıyla köleliğe düşmeyi içeren bu iki maddeye bakarak, çobanın ve "yönetici" olarak karşılığı verilen LớAGRIG' in ${ }^{26}$ toplumda alt bir sınıfa ait olmaları gerektiği yolunda yorumlar haklı olarak yapılmaktadır ${ }^{27}$. Özgür kadın eğer kendisinden daha alt düzeyde biriyle, belki bir köle ile evlendiğinde köle durumuna düşecektir. 175.maddede öngörülen iki ya da dört yıllık süre ise evliliğin geçerli olması için geçmesi gereken süre olmalıdır. Kanunlardaki bu ifadelere bakarak çobanların köle sınıfından olduklarını söylemek mümkün değildir. Çünkü çobanlarla ilgili diğer kayıtlardan bu yönde hiçbir işaret elde edilemez.

${ }^{21}$ KBo XVI 61 Rs 13. Bak. R. Werner, Hethitische Gerichtsprotokolle, StBoT 4, Wiesbaden 1967, s. 62.

${ }^{22}$ E.Laroche, Les Noms des Hittites, Paris 1971, s.70 no.385a.

${ }^{23} \mathrm{KBo}$ VI 2 II 6 (=KBo VI 3 II 25-26) ( \$35) ve KBo XXV 85 4-6+KUB XXIX $292-4$ (=KBo VI 26 II 17-20) (\$175). Bak. H.A.Hoffner, The Laws of the Hittites, A critical Edition, Leiden 1997, s.43 ve 139; F.Imparati, Hitit Yasaları, çev.E.Özbayoğlu, Ankara 1992, s.56-57 ve 162-163.

${ }^{24}$ Hoffner, The Laws of the Hittites, s.43; Imparati, Hitit Yasalan, s.57.

${ }^{25}$ Hoffner, The Laws of the Hittites, s.139; Imparati, Hitit Yasalan, s.163.

26 LU AGRIG için bak. I.Singer, "The AGRIG in the Hittite Texts," An.St. 34(1984), s.97 vd.

${ }^{27}$ Hoffner, The Laws of the Hittites, s.111; Imparati, Hitit Yasalan., s.207-208. 
Kanunların 80.maddesinde, bir koyunu kurda kapturan kişinin, koyunun etini sahibine teslim etmesi gerektiği, ancak derisini kendisinin alacağı belir$\operatorname{tilir}^{28}$. Burada söz konusu kişinin çoban olabileceği akla gelmektedir ${ }^{29}$. Yorumlanması güç olan bu kanun maddesinde, her ne kadar açıkça ifade edilmese de, hayvancilığın ve dolayısıyla çobanlığın önemli bir yer tuttuğu Hitit toplumunda bir takım sorumluluklarının kanunlara yansıyabildiğini görüyoruz.

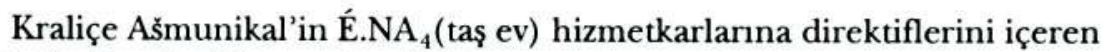
metinden ${ }^{30}$ anlaşıldığına göre $\mathrm{E} . \mathrm{NA}_{4}=$ taş evin (anıt mezar?) bakımı ve giderleri için bazı köyler ahalisi ile birlikte vakfedilmiş, bunlar vergi ve angaryadan muaf tutulmuşlardır. Vakfedilen köylerin, zanaatkarları, çiftçileri, koyun çobanlanı, sı̆̆ır çobanları ile birlikte verildikleri ifade edilmektedir ${ }^{31}$. Temel olarak tarım ve hayvancılığa dayanan Hitit kırsal kesim ekonomisinin, bir köyün ahalisini oluşturan grupların sayıldığı direktif metnine yansımasında koyun ve sığır çobanlarının ayrı ayrı sayılmasına dikkat edilmelidir.

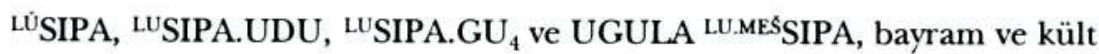
törenleri, ritüel ve dualarla ilgili metinlerde, direktif metinlerinde yukarıda değindiğimiz örnekteki taş ev hizmetkarlarına verilen direktiftekinden çok daha farklı anlam ve içerikte tapınakla ilişkili ya da dinsel anlamdaki uygulamalarla bağlantulı olarak geçmektedirler.

Yukarıda sıraladığımız "çoban", "koyun çobanı", "sığır çobanı" ve "çobanların başı", çeşitli türdeki çivi yazılı metinlerde geçmektedirler. Bunların geçtikleri yerlere bakılarak metinlerin içeriği, söz konusu sözcük ve terimlerin hangi bağlamda geçtiklerinin göz önünde bulundurulması yoluyla, bu unvanlar hakkında bilgiler edinmek ve yorumlarda bulunmak mümkün olmaktadır.

İgili metinleri ayrı ayrı ele almadan önce genel olarak şunu söylemek gerekir ki, doğrudan çoban anlamında ya da çobanlıkla ilgili bir terim olarak karşımıza çıkan bu unvanları taşıyan kişiler, sözcüğün asıl anlamıyla uyumlu olmak üzere çobanlık yapanlar ve elbette bunun yanı sıra bu işi tapınak için,

${ }^{28}$ Hoffner, The Laws of the Hittites, s.85.

${ }^{29}$ Hoffner ilgili yerde çeviride parantez içinde çoban olarak verir. Ayrıca Beckman, Fs. Otten, s.42'de ayn şekilde yorumlar.

${ }^{30}$ KUB XIII 8. Bu metin için bak. H.Otten, Hethitische Totenrituale, Berlin 1958, s.106 vd.

${ }^{31}$ KUB XIII 8 Vs. $1-4$. 
tapınak adına ya da başka türlü dinsel bağlamda yürüten kişilerdir. Çobanlık yapan, yani kırsal alanda olsun kentlerde olsun hayvanların bakımıyla, otlatulmasıyla vs. ilgilenen çobanların yanı sıra tapınak adına bu işi yapan, tapınağın hayvanlarıyla ilgilenen çobanlar ve taşıdıkları unvanlar dolayısıyla çobanlıkla ilgili görülen, ancak elimizdeki kayıtların yetersizliği dolayısıyla ne iş yaptukları ve konumları net olarak ortaya konulamamakla beraber doğrudan çobanlık yapmadıklarını söyleyebildiğimiz görevliler vardır.

Tapınakla bağlantılı ya da doğrudan tapınakla ilişki kurulamamakla beraber dinsel bağlamda rastladığımız bu görevlileri, çoğunlukla fragmanter olan, dolayısıyla çoğundan tam anlamıyla yararlanılamayan, bayram törenlerini, ritüelleri konu alan metinlerde görürüz. Zaten söz konusu metinler içeriklerinin özelliği dolayısıyla kaydedilmiş olan görevliler hakkında ayrıntulı bilgi vermekten de uzaktır. Bunların yanı sıra masal, direktif, dua gibi belgelerde de söz konusu görevlilerin yer aldıkları görülmektedir.

II.Muršili'ye ait bir dua metnindeki şu cümleler ilginçtir ${ }^{32}$ :

“...Tanrılar için düzenli kurban ekmeğini hazırlayan kadınlar öldüler, bundan sonra onlar düzenli kurban ekmeği sunamayacaklar. Ahır ya da ağıldan kurbanlık koyun ve sığırları seçen sığır çobanları ve koyun çobanları öldüler ve ağıl [boştur]. Şimdi tanrılara yiyecek, içecek ve hayvan sunuları durdu..."

Yukarıdaki pasajdan anlaşılacağı gibi kral, ülkedeki salgın hastalık dolayısıyla çok ölümler olduğunu, böyle devam ederse tanrılara kurbanlar sunacak kimsenin kalmayacağını duasında belirterek, daha sonraki saturlarda tanrıları kendi iyilikleri için salgın hastalığı ülkeden kovmaya davet etmektedir. Bizim açımızdan önemli olan koyun çobanları ve sığır çobanlarının tanrılara sunulacak kurbanlık hayvanları ahır ve ağıldan seçen kimseler olarak gösteriliyor olmasıdır. Ancak bunların kurban takdim ettiklerine dair bir ifade yoktur. Aşağıda ele alacağımız bir başka metin vasıtasıyla bu konuya tekrar döneceğiz, ama burada şunu vurgulamak gerekir ki yukarıda alıntı yaptığımız belgeden farklı olarak aşağıda ele alacağımız metinde "koyun çobanları ve sığır çobanları" ile "tanrının koyun çobanları ve tanrının sığır çobanları" ifadeleri ayrı ayrıdır.

${ }^{32}$ KUB XXIV 3 II 9-15. Metnin bu saturları için bak. O.R.Gurney, Hittite Prayers of Mursili II, Liverpool 1940, s.26-27; R.Lebrun, Hymnes et Prieres Hittites, Louvain-La-Neuve 1980, s. 160,169 . 
Söz konusu diğer metin, tapınak görevlileri ile ilgili bir direktif metnidir. Kolofonunda "tanrının sığır çobanları ile tanrının koyun çobanları"nın da içinde yer aldığı tapınak görevlilerine verilen direktifi içerdiği gösterilen bu metinde ${ }^{33}$ konumuzla ilgili saptamalara olanak tanıyan bölümler vardır.

Metinde bizi öncelikle ilgilendiren bölümler 18. ve 19. paragraflardır. Burada tanrılara yapılacak hayvan sunularında görevlilerin yapması muhtemel yolsuzluklara karşı uyarı yapılmaktadır. 18. paragrafın baş tarafı şöyle$\operatorname{dir}^{34}$ :

"Ayrıca tanrının sığır çobanları $\left({ }^{\text {LÚ.MES }}\right.$ SIPA.GU $_{4}$ DINGIR $^{\text {LIM }}$ ) (ve) tanrının koyun çobanları $\left({ }^{\text {LU.MES SIPA.UDU DINGIR }}{ }^{\text {LIM }}\right)$ olan sizler, eğer (hayvanların) doğum zamanında herhangi bir tanrıya (yapılacak) ibadet (varsa) ona ya buzağı, kuzu, oğlak ya da SALITU (ve) HAKURRATU sunarsınız. Onları geciktirmeyiniz. Onları tam zamanında sununuz..."

Burada üzerinde durulması gereken Lú.MEŚSIPA.GU DINGIR $^{\text {LIM }}$ "tanrının sığır çobanları" ve LÚ.MEśSIPA.UDU DINGIR LIM "tanrının koyun çobanları"ifadeleridir. Nitekim kolofonda ${ }^{35}$ da aynı şekilde geçer. Anlaşılan tapınakta görevli olan bu unvanı taşıyan kişiler vardı. Bunların görevleri de tanrılara hayvan kurbanlarını sunmaktı. Nitekim metinde açıkça bu belirtilmektedir. DINGIR LM "tanrının" olarak nitelenen unvanı taşıyan bu kişiler tapınaklarda tanrılara sunulması gereken hayvan kurbanlarını organize eden ve sunanlar olmalıdır. Yine metinden anlaşıldığına göre bu işin belli kuralları ve gelenekleri vardır. Hayvanların doğum zamanında tanrılara kuzu, oğlak ya da buzağı sunulması, taze şeylerin, yukarıda verdiğimiz saturların devamından anlaşıldığı üzere, hiçbir insan tatmadan önce tanrılara sunulması gerekiyordu ${ }^{36}$. Bu kuralın üzerinde hassasiyetle durulmaktadır. Tanrılara ait taze, ilk ürün olan yiyeceklerden görevlilerin kendilerinin faydalanmaları çok ağır bir suç olarak kabul edilmektedir ${ }^{37}$. Tüm bunlar bize tanrının sı̆̆ır ve koyun çobanlarının tanrılara hizmetle görevli kişiler olduğunu, ve bu metinde bahsi geçen süt bayramı örneğinde ${ }^{38}$ olduğu gibi bayram törenle-

${ }^{33}$ KUB XIII 4. Bu metnin işlendiği yerler olarak bak. A.Süel, Hitit Kaynaklarında Tapınak Görevlileri İle İlgili Bir Direktif Metni, Ankara 1985; E.H.Sturtevant-G.Bechtel, A Hittite Chrestomathy, Philadelphia 1935, s.127 vd.

${ }^{34}$ KUB XIII 4 IV 34-38. Bak. Süel, Direktif Metni, s.80-81.

${ }^{35}$ KUB XIII 4 IV $78-81$.

${ }^{36}$ KUB XIII 4 IV $39-40$.

${ }^{37}$ KUB XIII 4 IV 46 ve $54-55$.

${ }^{38}$ KUB XIII 4 IV 41. 
rinde de görev aldıklarını anlatmaktadır. Bunu başka metinler vasıtasıyla da biliyoruz.

19. paragrafin kime hitaben başladığı açıkça anlaşılamıyor. Ancak metnin önceki bölümlerine baktığımızda, bir gruba hitap edildikten sonra diğer bir gruba yönelik cümleler araya girmediği sürece hep aynı gruba hitap edildiği görülüyor. $\mathrm{O}$ halde 19. paragraf da bir önceki paragrafın kendilerine yönelik olarak başladığı (ve kolofonda da belirtildiği üzere direktif metninin muhataplarından olan) "tanrının sığır çobanları" ve "tanrının koyun çobanları"na hitaben olmalıdır.

19.paragrafin baş tarafi şöyledir ${ }^{39}$ :

"Ayrıca (hayvanların ayrım (işini) yaptığınız zaman onları beyleriniz tanrılara sevk ederler. Ayrılan (hayvanların) yanında sığır ço-

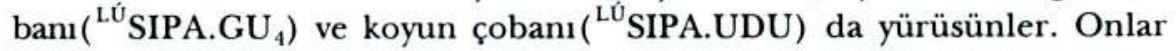
ahırda ve ağılda nasıl ayrılmışsa onları tanrılara aynı şekilde götürsünler. Onları yolda değiştirmesinler. Eğer yolda herhangi bir sığır çobanı ya da koyun çobanı hile yaparsa ya besili sığırı ya da besili koyunu değiştirir ve (onunla) alışveriş yaparsa ya da onu keserse ve onu yiyip bitirirlerse ve onun yerine zayıf (bir hayvanı) bırakırlarsa ve o meydana çıkarsa onlara ölüm cezası verilir..."

Pasajda gördüğümüz hayvanların ayrımı yani tanrılara yollanacak hayvanları seçme işi "tanrının sı̆̆ır çobanları" ve "tanının koyun çobanları"nın olmalıdır. Başka bir yerleşim yerindeki ya da kırsal bölgedeki hayvan barınaklarında tanrılara sunulacak en iyi hayvanlar seçiliyor ve bunlar da "beyler" tarafından sevk ediliyorlardı. Beyler yerel idareciler olmalıdırlar. Ancak sevk edilen hayvanlara refakat edenler ve yolda hile yapmasından kaygı duyulanlar LúSIPA.GU "sı̆̆ır çobanı" ve LúSIPA.UDU "koyun çobanı"dır. "Tanrının sığır çobanları" ve "tanrının koyun çobanları" ile "sığır çobanları" ve "koyun çobanları" arasında fark olduğu, yani ikisinin birbirinin yerine kullanılmadığı açıkça anlaşılmaktadır. Şöyle ki, ilk olarak, tanıının sığır çobanları ve tanrının koyun çobanlarına hitap edildiğini, kolofonda da bu unvanla yer aldıklarını daha önce de belirttik. İkinci olarak, doğrudan tanrının sığır çobanları ve tanrının koyun çobanlarına siz diye hitap edilir, sevk edilen hayvanlara refakat eden sığır ve koyun çobanına hitap edilmez. Onlar için "hayvanların yanında yürüsün, götürsünler, değiştirmesinler..."

${ }^{39}$ KUB XIII 4 IV 56-66. Bak. Süel, Direktif Metni, s.84-87. 
gibi, onları muhatap almayan, aracılar vasıtasıyla (ki bunlar tannının sığır çobanları ve tanrının koyun çobanları olmalıdır) talimat iletilir. Herhalde tanrının sığır çobanları ve tanrının koyun çobanları doğrudan tapınakta görevli, daha üst düzeyde, tanrılara hayvan kurbanı işini, ve bu işin kaynağını oluşturan tapınağa ait hayvan sürüleri ya da tapınağa kurban hayvanları gönderen kaynakları organize eden; tanrılara sunulacak hayvanları seçen ve sunan görevliler olmalıdır. Burada yer alan koyun çobanı ve sı̆̆ır çobanı ise doğrudan hayvanlarla ilgilenen, yani onların bakımı, otlatılması, getirilip götürülmesi işini yapan, kısacası asıl uğraşı çobanlık olan görevliler olmalıdır. Bunlar da tapınağa bağlı olarak çobanlık yapanlar olabileceği gibi, tapınağın dışında olup, tapınak için hayvanları getirip götürenler ya da tapınağın sahip olduğu sürülere bakan, bu sürülerle ilgilenenler olabilir. Bu metinden başka, yine çobanların geçtiği dinsel içerikli metinlerde de hem LÚ.MEśSIPA.GU ${ }_{4}$ DINGIR LIM "tanrının sığır çobanları" ve LÚ.MEŚSIPA.UDU DINGIR LIM "tanrının koyun çobanları" hem de L.ÚMEŠSIPA.GU ${ }_{4}$ "sığır çobanları", LÚ.MEsśSIPA.UDU "koyun çobanları" terimlerini ayrı ayrı görürüz ${ }^{40}$.

Tekrar söz konusu direktif metnine dönersek, tanrılara sunulmak üzere seçilen hayvanların hangi ahırdan, hangi ağıldan seçildiği (ahır ve ağıldan seçildiği satır 59'dan bellidir) açıkça belirtilmez. Yani tapınağın kendine ait ahırı ve ağılı olup olmadığı buradan belli olmamaktadır. Yolda hayvanların hileye uğrama ihtimalinin belirtilmesi ve bu hayvanlara çobanların refakat edecek olması yukarıda da değindiğimiz gibi bu ahır ve ağılın tapınaktan uzak olduğunu, belki bir başka yerleşim yerinde ya da kırsal alanda olduğunu gösterir. Belki de tapınağın kendi ahırı, ağılı ve bunlardan sorumlu görevlileri olmakla beraber, bunun yanı sıra değindiğimiz metinde olduğu gibi dışardan da tapınağa, tanrılara sunulmak üzere hayvanlar gönderiliyor olabilirdi. Ayrıca şunu gözden uzak tutmamak gerekir ki bir taraftan kendi işini yapan çobanlar aynı zamanda tapınağa karşı olan yükümlülüklerini de yerine getiriyor olabilirlerdi. Nitekim hayvanların değiştirilmesinden bahsediliyor. Ancak bu işi yapma ihtimali olanlar "tanrının çobanları" değil, öteki "tanrının" sıfatını taşımayan çobanlardır. Tanrının çobanlarının kendine ait sürüleri olduğu yönünde metinlerden herhangi bir işaret elde edilemiyor. Ancak bu metnin 16. paragrafinda "tanrıların çiftçileri"nin ekip biçmekle sorumlu oldukları tanıının (tapınağın) tarlası yanında kendi tarlaları da ol-

${ }^{40} \mathrm{KBo}$ XXIII 92 II 19; KUB XXV 31 Vs.13; KBo XXV 24 Vs 11 'de ${ }^{\text {LÚ(.MEŚ) }}$ SIPA DINGIR ${ }^{\text {LM }}$ "tanrının çobanı"; KUB XX 51 , KUB XXV 36 VI 18, KUB LVIII 16 Vs. II 12 "tanrının koyun çoban", KUB XX 10 IV 6, KUB XXV 31 Vs. 12,18"tanrının sığır çobanı" geçer. 
duğu anlaşılmaktadır ${ }^{41}$. Bu durumun "tanrının çobanları" açısından da geçerli olabileceği akla gelmektedir.

Bir ritüelde ${ }^{42}$ koyun çobanları ve sığır çobanları "bin ya da on bin" sayıları verilerek anılmaktadır ${ }^{43}$. Şüphesiz bu rakamlar çobanların gerçek sayıları olarak değil de, bir ritüeldeki gerçek üstü, abartılı sayllar olarak değerlendirilmelidir. Söz konusu ritüel metni gibi diğer ritüel, kült ve bayram, dua içerikli metinlerde "çoban" ve "tanının çobanı" terimleri geçer ${ }^{44}$. Ancak bunlardan söz konusu terimlerin Hitit kültüründeki yerine dair yorumlar yapılabilecek bilgiler edinmek mümkün olmamaktadır.

Bunların dışındaki bayram ve kült törenlerini, ritüel ve duaları içeren metinlerden çobanlık konusunda bu bağlamda fazla bilgi kazanılamamaktadır. Genel olarak bakıldığında "tanıının koyun çobanı", "tanrının sığır çobanı", "sığır çobanı" ve "koyun çobanı" ifadeleri metinlerde ayrı ayrı geçerler. Dikkati çeken nokta, bu tür metinlerde konumuz olan terimlerin "tanrının" ifadesi ile geçenlerinin sayısının çok olmasıdır. Bu da tapınakta görevli olan çobanların bu unvanı taşıdıklarına, yani bu unvanla görev yapan bir tapınak personelinin varlığına işaret eder.

Yine dinsel içerikli metinlerde UGULA LÚ.MEśSIPA "çobanların başı" geçer ki, bu unvanlı görevli sadece bu tür metinlerde karşımıza çıkmaktadır. Söz konusu terimin geçtiği tüm metinler bayram kutlamalarında koyun sunmayla ilgili görünmektedir ${ }^{45}$. Anlamına ve geçtiği metinlere bakarak tapınaktaki çobanların başı olabileceği, bayram kutlamalarında rol alan bir yönetici konumunda bulunabileceği ileri sürülebilir. Ancak kayıtların hiç birinde DINGIR ${ }^{L M}$ "tanrının" sıfatını taşımadığı da dikkati çeker.

${ }^{41}$ KUB XIII 4 IV 12-17.

${ }^{42}$ Tunnawi ritūeli. KUB VII 53+KUB XII 58. Bak. A.Goetze,The Hittite Ritual of Tunnawi, New Haven 1938.

${ }^{43}$ Goetze, Tunnawi, s.3.

4440 no'lu dipnotta verilen "tanrının çobanları", "tanrının koyun çobanları ve tanrının sığır çobanları"nın geçtiği belirtilen dinsel içerikli metin yerlerine ek olarak "çoban", "sığır ve koyun çobam"nın geçtiği diğer metin yerleri şunlardır: KUB XLIV 18 Vs. 15,16; KUB LVI 46+KUB XLIII 48 Vs.I 10; KUB VII 23 r.5; KBo XIII 257 Rs. 6; KBo XX 13 Rs. 9; KUB XLIV 38 Vs. 7; KUB XXIV 3 II 13; KUB XXLII 91 II 20; KUB XXIV 3 II [12; KUB XVII 21 III [4

${ }^{45} \mathrm{KBo}$ XVII 100 I 13; KBo XX 74 III 8; KUB XXV 27 II 11,12, KUB XXV 31 Vs. 11; KUB XL 73 IV 6. UGULA LÚ.MEŚSIPA'ya dair kayıtlar Daddi, Mestieri, s.26'da verilen bu metin numaralarından ibarettir. 
Bazı metinlerde "LÚSIPA"(çoban) terimi sarayla ilgili olarak geçmekle ${ }^{46}$ çobanların bulundukları farklı bir ortama daha tanıklık etmektedir. Hatta bunlardan birinin ismi "Wattihahla", şehir ismi de verilerek anılmaktadır ${ }^{47}$. Saraya ait hayvanlar bulunduğunu çivi yazılı metinlerde bir çok yerde karşımıza çıkan kayıtlarla biliyor olmamız, bunların sarayın ahır ve ağıllarındaki hayvanlardan sorumlu olan çobanlar olarak, doğrudan çobanlık yaptıkları yorumuna olanak tanımaktadır ${ }^{48}$.

GAL Lú.MEśSIPA saray çevresi ile ya da kültle ilgili olmak üzere metinlerde karşımıza çıkar ${ }^{49}$. GAL LÚ.MEs SIPA konusunda belgelere bakılarak bir yorum yapmak zordur. Ancak şu söylenebilir ki bu unvan her ne kadar "çobanların büyüğü" anlamına gelse de, onu taşıyanların doğrudan doğruya çobanlıkla ilgili bir iş yapıyor olup olmadıkları kesinlikle ortaya konulamaz. GAL LÚ.MEśSIPA unvanını taşıyan görevli, sözcük anlamına bakılırsa Lú.MEŠSIPA'nın lideri, bunların oluşturduğu grubun başı olabileceği akla gelmekle beraber terimin içinde çoban sözcüğünün geçiyor olması, bu unvanın mutlaka çobanlıkla ilgili olmasını da gerektirmez. Söz konusu unvanı taşıyanlar önemli bir idari, askeri vs. mevkide bulunuyor olmalıydılar. Nitekim bağış belgelerinde GAL LÚ.MEśSIPA unvanını taşıyan kişiler, yapılan bağışı şahitleri arasında saptanmaktadır ${ }^{50}$.

UGULA LÚ.MEšs SIPA “çobanların başı”, bayram kutlamalarında koyun sunulması ile ilgili olarak geçmektedir ${ }^{51}$. Metinlerde geçtiği saturlara bakılınca bu unvanı taşıyan kişinin bayram törenlerinde hayvan kurbanı sunulmasında rol alan bir görevli olduğu ortaya çıkmaktadır. Sumerogramın taşıdığı anlam itibariyle bunların tapınakta görevli tapınak sürüleriyle ilgilenen, hayvan

${ }^{46}$ HT 39 46; KBo X 23 VI 18-19; KBo XVI 83 II 4; KUB XXII 27 IV 29,34,36=KBo XXIV

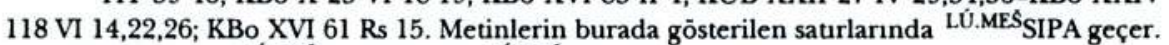
Sarayla ilgili olarak LÚ.MEŚSIPA.UDU ve LÚ.MEŚSIPA.GU, geçmez.

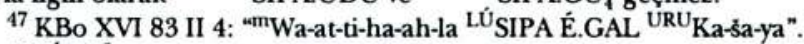

48 LÚ.MES SIPA sarayla ilgili olarak yer aldığı iki metinde "sağ" ve "sol" olmak ūzere belirtilmektedir. HT 39 Rs. 6-7 ve KBo X 23 VI 18-19. Bu konuda bak aşağıda s.17.

${ }^{49}$ Bak. Daddi, Mestieri, s.549.

${ }^{50}$ KBo V 7 Rs. 53. Bak. K.K.Riemschneider, "Die hethitischen Landschenkungsurkunden" MIO 6/3 (1958) (=LSU), s.354 (LSU 1, 53). Burada GAL LÚ.MEŚSIPA ünvanh iki isim geçmektedir. Ancak bir ismin bas tarafi kurıkur. ${ }^{m}$......s $\mathrm{s} / \mathrm{t}$ ] a-zi-ti GAL LÚ.MESSIPA ZAG-az ${ }^{m}$ LUGAL ${ }^{\mathrm{D}} \mathrm{KAL}$ GAL LÚ.MES'SIPA GUB-la-az; KBo XXXII 185 Rs. 16'da "'Zuha GAL LÚ.MEŚSIPA ZAG-az geçer. Burada "sağ" (ZAG) ve "sol" (GUB)dan bahsedilmesi GAL LÚ.MEŚSIPA ünvanını taşıyanlarıı "sağ" ve "sol" olarak ayrıldıklarını gōsterir.

${ }^{51}$ Bak. Daddi, Mestieri, s.26. 
kurbanı sunma işini de organize eden, sunulacak hayvanları seçen çobanlar grubunun başkanı olduğu kabul edilebilir.

Dikkati çeken nokta, tapınakta görevli çobanlar "tanrının sığır çobanları ve tanrının koyun çobanları" olarak da geçtikleri halde "UGULA LÚ.MEśSIPA" teriminin "DINGIR ${ }^{L I M}$ " (tanrının) ile nitelenmiş örneklerinin olmamasıdır. Nitekim bir metinde koyun ve sığır çobanları "DINGIR LIM" olarak geçtikleri halde, onlardan hemen önce geçen "UGULA LU.MEsSIPA"da bu sıfat yer al$\operatorname{maz}^{52}$.

Metinlerde sığır çobanı, koyun çobanı, domuz çobanı gibi belli bir hayvana göre tanımlanan çobanlardan biri de keçi çobanıdır. Konumuz açısından keçi ile ilgili olarak Hititçe çivi yazılı metinlerde yer alan sumerogramlar LÚ MÁS.GAL LúSIPA.UZ ${ }_{6}$ 'dur. Her ne kadar sadece birinde doğrudan çoban (SIPA) geçiyor olsa da ikisinin de karşılığı keçi çobanı olarak verilmektedir. Bunlardan ${ }^{\text {LúSIPA.UZ }} 6{ }_{6}$ 'un LÚSIPA.GU ${ }_{4}$ ile peş peşe geçtiği bir metin ${ }^{53} \mathrm{kırık}$ olduğu için herhangi bir bilgi kazanılamaz. LúMÁŠ.GAL tarihsel ${ }^{54}$ ve bunun yanında kült ve bayram içerikli ${ }^{55}$ metinlerde yine hayvan kurbanı ile ilgili olarak karşımıza çıkar. Düzenlenen törenlerde Ló MÁŠ.GAL'in, sumerogramın taşıdığı anlamla uyumlu olarak bir rolü olduğu dikkati çeker. Tarihsel içerikli belgelerdeki geçişi ise Tarhuntaššalı Ulmi-Tešup ile III.Hattušili arasında yapılan anlaşmada, Tarhuntašša'nın sınırları belirlenirken "keçi çobanının girişinin yasaklanması" ifadesi iledir ${ }^{56}$. Anlaşma ile Tarhuntašša ülkesi kralına verilen otlaklar ve tuzlalardan bahsedilir. Bunlar dolayısıyla LửMÁŠ.GAL'in kırsal alandaki asıl işleviyle geçtiğini anlıyoruz.

LúSIPA.ŠAH "domuz çobanı" bir dua metninde geçer ${ }^{57}$. Tanrıların vebayı Hatti ülkesinden kovması için yapılan duada Kaškalar'dan bahsederken onları küçümsemek için olsa gerek "domuz çobanı ve keten

${ }^{52}$ KUB XXV 31 Vs. 13.

${ }^{53}$ KUB LII 43 Vs. 10.

${ }^{54} \mathrm{KBo}$ IV 10 Vs. 33; VI 28 Rs. 24; 29 III 28.

${ }^{55} \mathrm{KBo}$ XIV 21 II 38;KBo XVII 105 III 15;KBo XXII 60 Rs.7(=KUB XXVI 43 Rs.11) KUB XX 42 I 16] (?); KUB XLVI 28 Vs. 8; VBoT 122 I 5 [ ; IBoT III 100 Vs.4; KUB LIX 34 Vs. II 6 ve KUB XLVI 28 Vs 8.

${ }^{56} \mathrm{KBo}$ IV 10 Vs. 33-34. Bak. H.A.Hoffner, "The Ulmitesup Treaty (KBo 4.10=CTH 106) with a New Join," Anatolia and the Ancient Near East, T.Özgüç'e Armağan, Ed. K.Emre ve diğ., Ankara 1989, s.200; G. Beckman, Hittite Diplomatic Texts, Atlanta 1996, s.105.

${ }^{57}$ KUB XXIV 3 II 37. Bak. O.R.Gurney, Hittite Prayers of Mursili II, Liverpool 1940, s.2829; R.Lebrun, Hymnes et Prieres Hittites, Louvain-La-Neuve, s.162, 170. 
dokuyucu" ifadesi kullanılır ${ }^{58}$. Nitekim salgın hastalık dolayısıyla sıkıntuya düşen Hatti'ye bir de isyanların darbe vurduğundan söz edilmektedir aynı yerde. Şu halde "domuz çobanı" ve "keten dokuyucu" Hititler'de aşağı, küçümsenecek bir iş olarak görülüyor olmalıydı. Bir metinde Lú.MEśSIPA.UDU ile peş peşe geçen LÚŠAH da "domuz çobanı" anlamına gelmektedir ${ }^{59}$. LúSIPA.ŠAH ve LúŠAH'ın karşıllı̆ı olarak "domuz çobanı" verilebilmekle beraber, bu terimin Hitit tarihi ve kültüründeki yerini daha geniş̧̧e ögrenebileceğimiz çivi yazılı kayıtlardan yoksunuz.

"Domuz çobanı" teriminin Hititçe çivi yazılı metinlerde domuzla özel olarak ilgilenen bir çoban olduğunu bize göstermesi ve bu terimin yukarıda değinildiği gibi çok sınırlı örnekle temsil edilmiş olmasına karşın, hayvan olarak domuz (ŠAH) pek çok metinde karşımıza çıkar ${ }^{60}$. Bunun yanı sıra kimi arkeolojik malzeme üzerinde domuz tasvirleri olduğunu da biliyoruz ${ }^{61}$. Domuz etinin Hititlerce yenildiği, ekonomik açıdan bu yönüyle bir değer ifade eden bu hayvanın derisinin de kıymetli olduğ ${ }^{62}$ bilinmektedir. Ancak domuz Hititlerce de dinsel açıdan "temiz olmayan" hayvan olarak kabul edilmekteydi.

LÚ $^{\mathrm{MES}}$ (ŠE).KIN.KUD "hasat işçileri” bazen hayvanlarla da meşgul olarak kaydedilmişlerdir. Sınır muhafız komutanlarına yönelik talimatnamelerden birinde şu satırlar okunur ${ }^{63}$ :

"Sığır, koyun ve hasat işçilerinin kasabadan çıkmasına izin verilmesin. Akşam olunca gözetleyiciler geri gelsinler ve gözetleme yerlerini tutsunlar. [... Gözetleyiciler yolları] gündüz gözetlesinler, [aynı şekilde geceleyin] de gözetlesinler, hasat işçileri, sığırları, koyunları, atları, eşekleri önde koştursunlar ve onları yukarı sevk etsinler".

Hititçe çivi yazılı metinlerde geçen ve "çoban" anlamına gelen bir başka

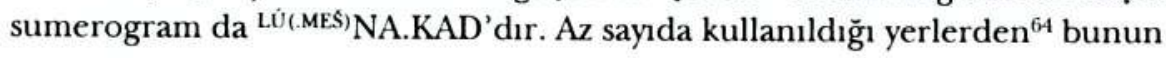

${ }^{58}$ Bu metinde geçen "domuz çobanı" ile ilgili olarak bak. H.A.Hoffner, "Die Kaskaer.Ein Beitrag zur Ethnographie des Alten Kleinasien, by E. Von Schuler, Berlin 1965," JAOS 87/2(1967), s. 183 .

${ }^{59} \mathrm{KBo}$ XII 132 Vs. 6.

${ }^{60}$ Ertem, Fauna, s.71 vd.

${ }^{61}$ Ertem, Fauna, s.73-74.

${ }^{62}$ Hoffner, JAOS 87/2(1967), s. 183.

${ }^{63}$ KUB XIII 1 Vs I 17-22. Bak. A.Goetze, "The Beginning of the Instructions for the Commander of the Border Guards," JCS 14(1960), s.69-73.

${ }^{64}$ Bak. Daddi, Mestieri, s.21. 
hakkında fazla bilgi edinilememektedir. Lú.MEśNA.KAD kült metinlerinde hayvan kurbanı sunarken görülür ${ }^{65}$. Geniş yoruma olanak veren kayıtlar olmamakla birlikte, LÚ(.MEŚ) NA.KAD'ın sarayla ilgisi olan bir görevli, aynı zamanda kült işlerinde görev alan, hayvan kurbanı sunan görevli olduğu söylenebilir. ${ }^{L U(}($ MEŚ) $N A . K A D ' ı n$ sarayda ya da tapınakta çobanlık yapıp yapmadığını, yani sarayın ve tapınağın hayvan sürülerini gözetim altunda bulunduran görevliler olup olmadıklarını söylemek, elimizdeki bilgilerle mümkün değildir. Ancak aşağıda ele alacağımız GAL NA.KAD "çobanların büyüğü" unvanını taşıyan görevliler ile ${ }^{L U ́(}\left(\right.$ MESS $\left.^{\prime}\right)$ NA.KAD'ın bir bağlantısı olduğu düşünülürse -belgelerde bu yönde hiçbir kanıt olmadığı hemen belirtilmelidirLÚ(MES') NA.KAD'ın çobanlık yapmadıkları ihtimali güçlenir. Nitekim LúSIPA söz konusu olduğunda rastladığımız çeşitli evcil hayvan isimlerine göre isimlendirmeye ${ }^{\mathrm{LU}(\mathrm{MES})}$ NA.KAD'da rastlanmaz. Belki bu isim yaptıkları iş dolayısıyla, yani dinsel törenlerde kurban olarak hayvan sunusu yaptıkları için sembolik olarak verilmiş olabilir.

UGULA LÚ.MEŚNA.KAD unvanıyla metinlerde rastladığımız görevli de herhalde bu sumerogramın işaret ettiği gibi ${ }^{L U}($ MEŚ) NA.KAD olarak rastladığımız görevlilerin başı (lideri) olmalıdır. Bunlar da yine bir kaç bayram metninde görülürler ${ }^{66}$.

GAL NA.KAD “çobanların büyüğü" Hititçe çivi yazılı metinlerde diğer çoban sözcüğüyle ilgili unvanlarda olduğu gibi az sayıda geçer ${ }^{67}$. Söz konusu kayıtların hepsi birden göz önünde bulundurulduğunda, bu unvanın tanımlanması konusunda kesin bir sonuç ortaya çıkmaz. Ancak, kayıtlardan birinde GAL NA.KAD'ın askeri bir unvan, bir komutan olduğu yolunda çok güçlü ifade vardır ${ }^{68}$. I.Šuppiluliuma'nın icraatının anlatuldığı bu metinde Šuppiluliuma Almina'nın tahkimi işi ile meşgulken Urawanni ve GAL NA.KAD unvanlı Kuwatnaziti'yi Kaška ülkesine saldırmaya yollamıştır ${ }^{69}$. Görüldüğü gibi GAL NA.KAD unvanını taşıyan Kuwatnaziti, Šuppiluliuma'nın ordusuna kumanda edenlerden, üst düzeyde komutanlardan biri olmalıdır.

${ }^{65}$ KBo XXII 246 II 15: "12 UDU LÚ.MEs NA.KAD pi-iš-kán-zi ..."

${ }^{66}$ KUB XI 30 IV 15;KUB XXV 27 I 30; KUB LI 36 Vs. 2.

${ }^{67}$ Daddi, Mestieri, s.540.

${ }^{68} \mathrm{KBo}$ V 6 I 32=BoTU 41. Bak. Güterbock, JCS 10, s.91.

${ }^{69}$ KBo V 6 I 31-33.Bak. Güterbock, JCS 10, s.91: (31) nu ku-it-ma-an URU Al-mi-na-an [(u-e-

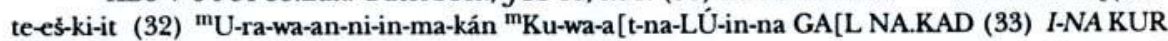
${ }^{U R U} U_{\mathrm{Ka}-\mathrm{a}-\delta ̌ u-l a ~ G U L-a}$ [(h-hu-wa-an-zi pa-ra-a)] na-eš-ta "o Almina'yı tahkim ederken, Urawanni ve GAL NA.KAD Kuwatnaziti'yi Kašula şehri ülkesine saldırmaya yolladı..." 
GAL NA.KAD kanunlarda bir maddede de geçer ${ }^{70}$. Sonundan yarım sat1rın silinmiş olduğu söz konusu kanun maddesinde yazıcı (DUB.SAR) Hanikuili geçer. Bu ismin yer aldığı saturdan hemen üç satır sonra aynı isim GAL NA.KAD unvanıyla anılır. Muhtemelen bu iki ayrı unvanı taşıyan aynı kişi olmalıdır.

GAL NA.KAD unvanını taşıyan bir kişinin bunun yanı sıra başka unvanlar da taşıdığını gösteren bir başka belge daha vardır. Bu bir toprak bağış belgesidir $^{71}$. IV.Tudhaliya tarafindan Sahurunuwa adlı birine toprak bağışının yapıldığı belgede Sahurunuwa metnin birkaç yerinde sadece GAL NA.KAD unvanı ile görülürken ${ }^{72}$, bir yerde GAL DUB.SAR.GIŠ "tahta tablet katiplerinin başı", GAL UKU.UŠ "ağır silahlı askerlerin başı" ve GAL NA.KAD "çobanların büyüğü" unvanlarının üçü ile birden görünür ${ }^{73}$. Prens olabileceği ileri sürülen Sahurunuwa'nın, prens olmasa bile taşıdığı unvanlara bakılarak üst düzey bir görevli ya da komutan olduğu anlaşılmaktadır ${ }^{74}$. Taşıdığı üç unvanın aynı zamanda kullanılmadığı, birbirini takip eden zamanlarda kullanıldığı da ileri sürülür ${ }^{75}$. Ancak yukarıda da belirttiğimiz gibi kanunlarda da GAL NA.KAD unvanını taşıyan Hanikuili adındaki kişi DUB.SAR "yazıcı" unvanı ile de anılır. Bu unvanların aynı kişi tarafından aynı zamanda taşınmış olup olmadıkları yanıtı kesin olarak ortaya konulamayan bir sorudur.

Bahse konu olan belgenin bir toprak bağış belgesi olduğunu belirttik. Burada kendisine bağış yapılan GAL NA.KAD unvanlı Sahurunuwa'nın yanı sıra, yine aynı unvanı taşıyan Mizranuwa adlı biri de tanık olarak yer alır. Bu şahsın unvanı GAL NA.KAD GUB-la-aš yani "solun GAL NA.KAD'ı"dır" Mizranuwa'nın bir askeri görevli olduğu başka belgeler yardımıyla ortaya konulabilmektedir ${ }^{77}$. Şu halde GAL NA.KAD unvanının bir askeri görevliye ait olduğuna dair bir başka kanıt da burada karşımıza çıkmaktadır. Böylece GAL NA.KAD'ın "sağ" ve "sol" olarak ayrıldığına da değinmiş oluyoruz. Sa-

${ }^{70} \mathrm{KBo}$ VI 4 kolofon 4. Bak. Imparati, Hitit Yasalari, §XLI satur 4, s.116.

${ }^{71}$ KUB XXVI 43. Bak. F.Imparati, "Una Cocessione di Terre da Parte di Tudhaliya IV," RHA 32(1974), s.24-39; L. M. Mascheroni"In Margine a una clausola Testamentaria (KUB XXVI 43 Ro 51-52)," SMEA 22(1980), s.63-66.

72 KUB XXVI 43 Vs. $4,14,17$.

${ }^{73}$ KUB XXVI 43 Vs. 49.

${ }^{74}$ R. H. Beal, The Organization of the Hittite Military, Heidelberg 1992, s.382 vd., 392 vd.

${ }_{75}^{75}$ Beal, Hittite Military, s.392.

${ }^{76}$ KUB XXVI 43 Rs. 31

${ }^{77}$ Beal, Hittite Military, s.393. 
hurunuwa'nın taşıdığı diğer iki unvan da aynı şekilde belgelerde "sağ" ve "sol" olarak ayrılmaktadır ${ }^{78}$. GAL NA.KAD'ın "sağ" ve "sol" olarak ayrılması onun ordunun organizasyonunda söz konusu unvanı taşıyan üst düzeydeki komutanın hangi tarafta bulunduğu ile ilgili olabileceği ileri sürülmekte$\operatorname{dir}^{79}$. Bu sumerogramın kökünde yer alan (LÚ.MES) NA.KAD ve yine bununla aynı anlamdaki (LÚ.MES) SIPA'nın ve bunlardan başka GAL (LÚ.MEŚ) SIPA'nın da geçtiği kimi yerlerde "sağ" ve "sol" ayrımı ile tespit ediliyor olmalarını da burada belirtmek gerekir. Sıradan çobanlar "sağ" ve "sol" olarak ayrılırken, kelime anlamına göre onların lideri durumunda olarak görünen GAL NA.KAD da bu şekilde bir ayrıma tabi olmuş ve daha sonra bu bir askeri unvan olduktan sonra da bu şekliyle devam mı etmiştir? Bu soruyu yanıtlamak zordur ${ }^{80}$.

GAL NA.KAD ile ilgili olarak söylenebilecek şeyin, bunun bir askeri unvan olduğunu yukarıda belirttik. Zira bir metinde yer alan kayıtlanı açıkça bu yönde yorumlamak mümkün iken, bir diğerinden dolaylı olarak buna destek veren saptamalar yapılabilmektedir. Bu askeri unvanın, sumerogramın asıl anlamıyla yani çobanlıkla ne gibi bir bağlantısı olabileceği net olarak ortaya konulamaz. Çobanların başı/büyüğü anlamı ve çobanlık mesleği, yani hayvanları idare eden kişi anlamı ile bir komutanın yaptığı işin temeldeki benzerliğinin göz önüne alınması da ilk anda akla gelir. Bu unvanın sonradan $\mathrm{m}$ askeri bir unvan olarak değiştiği (geliştiği) de cevabı net olarak ortaya konulamayan bir başka sorudur. GAL ${ }^{(L U ́ . M E S)}$ SIPA'nın Eski ve Erken Orta Hitit belgelerinde geçtiği, GAL NA.KAD'ın ise Yeni ve Geç Orta Hitit belgelerindeki, GAL (LÚ.MES)SIPA'nın versiyonu olabileceği ileri sürülmektedir ${ }^{81}$.

Hayvanların beslenmesi, bakımı ve korunması ile ilgilenen çobanlara ilişkin konuda hayvanların barınaklarına da değinmek yerinde olur. Bununla ilgili olarak metinlerde karşımıza öncelikle iki Hititçe sözcük çıkmaktadır. "Hali" ve "ašawar". Bunlardan "hali", "büyükbaş hayvan barınağı, ahır" anlamına gelmektedir ${ }^{82}$. "Ašawar" ise "küçükbaş hayvan barınağı, ağıl" anlamındadır ${ }^{83}$. Metinlerde geçtikleri yerler bu sözcüklerin bu anlamlarını açıkça ortaya koymaktadır. Hitit kanunlarının 66.maddesinde hangi hayvan-

${ }^{78}$ Beal, Hittite Military, s.383-385.

${ }^{79}$ Beal, Hittite Military,s.393.

${ }^{80}$ Bu konudaki tartşmalar için bak. Beal, Hittite Military, s.395.

${ }^{81}$ Beal, Hittite Military, s.394.

${ }^{82}$ J.Friedrich, Hethitisches Wörterbuch, Heidelberg 1952, s.46; J.Puhvel, Hittite Etymological Dictionary, vol.3, Mouton-Berlin 1984,s.26.

${ }^{83}$ Friedrich, Hethitisches Wörterbuch, s.35. 
ların "hali" hangisinin "ašawar"da barındırıldıkları konusunda bilgi verilmektedir. Kanun maddesi şöyledir ${ }^{84}$ :

"Eğer bir çift öküzü, eğer bir koşum at, eğer bir inek, eğer bir dişi eşek <başka> ahırlara (ha-a-li-ia-aš) ayrılırsa (sürülürse), eğer bir evcil keçi, eğer bir koyun, eğer bir koç <başka> bir ağıla (a-ša-u-ni) ayrılırsa (sürülürse), <ve eğer> onun sahibi onu bulursa ve onu tamamen dokunulmamış olarak alırsa, bir hırsız gibi yakalanmasın"

Burada görüldüğü gibi at, inek, eşek gibi büyükbaş hayvanların barınağı olarak "hali" geçmektedir. Keçi ve koyun gibi küçükbaş hayvan barınağı olarak da "ašawar" geçmektedir.

Bunun dışında yine sığırın "hali", koyunun da "ašawar"la ilgili olduğuna dair örnek vermek gerekirse, yukarıda değindiğimiz tapınak görevlilerine dair direktif metninde şu saturlar okunur ${ }^{85}$ :

“... ve o (besili) sığırı ya yiyip bitirirseniz ya da onu (size ait olan) ahıra(ha-a-li) bırakırsanız ya da onu boyunduruğa koşarsanız ya da (besili) koyunu (size ait olan) ağıla(a-ša-u-ni) bırakırsanız..."

Burada tapınak görevlilerine tanrılar için ayrılmış olan hayvanları kendileri için kullanmamaları ya da sahiplenmemeleri için uyarılar yapılmaktadır.

Aynı metnin herhalde tapınakta görevli olan, tanrının sığı çobanları ve tanrının koyun çobanlarına hitap eden kısmında yine tanrılar için, tapınağa ulaşturılmak üzere seçilip ayrılmış hayvanların herhangi bir hile yapılmadan tapınağa ulaşurılması konusundaki talimattan ilgili kısmı şöyledir ${ }^{86}$ :

“... Ayrılan (hayvanların) yanında sığır çobanı ve koyun çobanı da yürüsünler. Onlar ahırda ve ağılda nasıl ayrılmışsa onları tanrılara aynı şekilde götürsünler"

Burada görüldüğü gibi sığır çobanı ve koyun çobanı doğrudan doğruya kurbanlık hayvanlarla ilgilenen kişiler olup hayvanların ayrıldıkları(seçildikleri) yer de ahır ve ağıldır. Hayvanların seçilmesi işini yapanlar bizzat çobanlardır. Bu durum yukarıda alıntı yaptığımız bir dua metnindeki

${ }^{84} \mathrm{KBo}$ VI 3 III 51-54. Bak. Hoffner, The Laws of the Hittites, s.76-77; Imparat, Hitit Yasalan, s.80-81.

${ }^{85}$ KBo XIII 4 Vs. II 14-17. Bak. Süel, Direktif Metni, s.36-39.

${ }^{86} \mathrm{KBo}$ XIII 4 Rs. IV 57-60. Bak. Süel, Direktif Metni, s.87. 
anlatımla da ortaya konulabilmektedir ${ }^{87}$. Söz konusu saturlarda II.Muršili ülkesindeki hastalığı kovması için tanrılara yakarırken, ahır ya da ağıldan kurban hayvanlarını seçen çobanların öldüğünü, dolayısıyla tanrılara hayvan kurbanı sunusunun durduğunu söylüyordu.

Bunların dışında É.GU ${ }_{4}$ sumerogramı ile gösterilen "sığır ahırı" vardır. BEL MADGALTI (kale komutanı) için gönderilen talimatnamelerden birinde geçer. Eskidiği için tamiri yapılması gereken yerler arasında kralın evleri, sığır ahırları, depolar, yıkanma evi saylır ${ }^{88}$.

Bir başka metinde de domuz barınağından söz edilir. "SAH GIM-an huu-um-ma" ${ }^{89}$ geçer. III.Hattušili'nin otobiyografisi olarak adlandırılan bu belgede yeğeni Urhi-Tešup ile olan mücadelesinin anlatıldığı yerde şöyle bir ifade vardır ${ }^{90}$ :

"Ištar'ın tanrısal gücünü çok gördüm. Urhi-Tešup'u başka hiçbir yere bırakmayarak onu Šamuha'da bir domuz gibi domuz ahırına kapatt..."

Çivi yazılı belgelerde küçükbaş ve büyükbaş hayvan barınaklarına dair bu kayıtlar yer almakla beraber, arkeolojik kazılarda Hitit dönemine ait olmak üzere hayvan barınağı olarak tanımlanabilecek bir mimari kalıntıya rastlanmamıștur ${ }^{91}$.

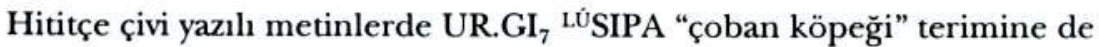
rastlanmaktadır ${ }^{92}$. Şüphesiz hayvan sürülerinin idaresinde ve korunmasında, ayrıca hayvan barınaklarının korunmasında çobanların yardımcısı olarak bugün olduğu gibi Hititler döneminde de çoban köpeklerinden faydalanılıyordu. Kanunlardaki 87. ve 88. maddeler çoban köpeğinin söz konusu işlevi dolayısıyla değerinin diğer köpeklere göre daha fazla olduğunu göstermektedir. Hitit kanunlarının çoban köpeği ile ilgili 87. maddesi şöyledir ${ }^{93}$ :

"Eğer bir çobanın köpeğini biri vurursa ve o ölürse, yirmi şekel gümüş versin ve <böylece suçu> evinden uzaklaşturır".

${ }^{87}$ Bak. yukanda s. 8 dn. 32.

${ }^{88}$ KUB XXXI 87 II 14-15(=KUB XIII 2 II 13-15).Bak. E. Von Schuler, Hethitische Dienstanwesungen, Graz 1957, s.44-45.

${ }^{89} \mathrm{KBo}$ III 6 Rs. III $57=$ KUB I 1 IV 26.

${ }^{90}$ Metnin bu saturlarını trankripsiyon ve Almanca tercümesi için bak. H.Otten, Die Apologie Hattusilis III, Wiesbaden 1981, s.24-25.

${ }^{91}$ J.Yakar, Ethnoarchaeology of Anatolia, Jerusalem 2000, s.278.

${ }^{92}$ Ertem, Fauna, s.96,99.

${ }^{93} \mathrm{KBo}$ VI 3 IV 22-23= KBo VI 7 5-6; Imparati, Hitit Yasalan, s.88-89. 
Tapınak görevlileri ile ilgili yukarıda değinilen direktif metninde sığır çobanları ve koyun çobanlarına talimatların iletildiği bölümde, tanrılar için tüm ürünlerin en tazesinin, henüz hiçbir insan tatmadan sunulması gerektiğinin belirtildiği yerde "süt bayramı"ndan (EZEN GA) bahsedilir. Ayrıca sütün yayıkta çalkalanması konu edilir ${ }^{94}$. Buradan anlaşılıyor ki yayıkta çalkalayarak süt ürünlerini elde etmek çobanların görevidir. Elbette burada söz konusu olan tapınakta görevli çobanlar ve dolayısıyla tapınakta ya da tapınağa ait hayvanlardan elde edilen süt ürünleridir. Nitekim "süt bayramı"ndan da bahsediliyor. Buna paralel olarak kırsal alanda ya da kent yaşamında da hayvanların bakımı, beslenmesi, korunmasından vs. sorumlu olan çobanların hayvanlardan ürünler elde edilmesi ve elde edilen ürünlerden de sorumlu olmaları doğaldır.

Çoban sözcüğünün Hititçe yazılı belgelerdeki karşılığı olan 'úSIPA'nın ve koyun çobanı karşılığı olan túSIPA.UDU'nun değişik bir kullanımı da Güneş Tanrısı'nın bir sıfatını oluşturan sözcük dizileri içerisinde yer almış olmalarıdır. Bu sözcük dizileri metinlerde karşımıza farklı biçimlerde çıkmakla beraber hepsinde verilmek istenen "insanlığın çobanı", "ülkenin çobanı" ve bunların yakın anlamlarıdır.

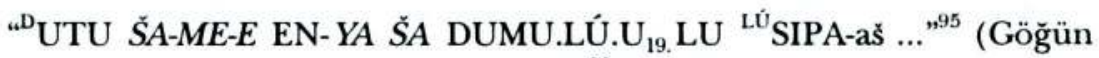
Güneş Tanrısı, efendim, insanlığın çobanı) ${ }^{96}$.

Bu metin Muwatalli'ye ait bir dua metnidir. Burada Güneş Tanrısına olan yakarmada onu tanımlarken "insanlığın çobanı ${ }^{\text {"9g7 }}$ sıfatuna yer verilmiştir.

Güneş tanrısına olan bir duada yine tanrının bu sıfat ile, ama bu defa daha farklı bir yazılışı ile karşılaşıyoruz.

${ }^{\text {“D}}{ }^{\mathrm{U}} \mathrm{TU}$-uš hu-u-m[a-an-da-aš] ${ }^{\mathrm{L} U}$ SIPA-ŠU-NU zi-ik” ${ }^{98}$ (Güneş Tanrısı sen tü[münün] çobanısın).

${ }^{94} \mathrm{KBo}$ XIII 4 Rs. IV 41-42. Bak, Süel, Direktif Metni, s.82-83.

${ }^{95}$ KUB VI 45 III 13; paralel metin KUB VI 46 III 52' de "LÙ SIPA-as" yerine "u-e-eš-ta-ra-aš" kullanılmışar.

${ }^{96}$ Lebrun, Hymnes, s.266, 280.

${ }^{97}$ Bir antlaşma metninde de Güneş Tanrısı'nın aynı sıfat taşıdığı görülür. HT 8 r.8: "[ DUTU] SA-ME-E LUGAL KUR KUR MES LÚSIPA.UDU SA DUMU.LÚ.U ${ }_{19}$ LU" (Daddi, Mestieri, s.25). (Güneş tanrısı, ülkelerin kralı, insanlığın çobanı).

${ }^{98}$ ABoT 44 a II 34. 
Mitolojik içerikli bir başka belgede de yine benzer anlamı verecek farklı ifadeler yer almaktadır. Bu metin Appu masalına aittir:

“D[UT]U-uš KUR-e<-an>-ta-aš Lú SIPA.UDU[-a]š ...”9 (Güneş Tanrısı ülkenin çobanı).

“İnsanlığın çobanı", "ülkenin çobanı" ve "tümünün çobanı", bu terimler Güneş Tanrısı'nın aynı anlama gelen sıfatının farklı söyleniş biçimleridir. Çoban sözcüğünün anlamı (yani hayvanları idare eden) göz önüne alındığında, bir tanrının bu sıfatı taşıyor olması, tüm Eskiçağ toplumlarında olduğu gibi Hititler'de de tanrıların insanların kaderinin belirlenmesindeki rollerine ilişkin anlayışla birlikte düşünüldüğünde anlam kazanır. Dikkati çeken nokta, bu sıfatı taşıyan Güneş tanrısının, tasvirlerde genellikle aynı tarz giyimde karşımıza çıkan diğer tanrılardan farklı olarak kralların da giymiş olarak gösterildikleri giysilerle tasvir edilmiş olması ${ }^{100}$ ve elinde taş1dığı asadır ${ }^{101}$. Güneş tanrısının elinde krallarda olduğu gibi bir asa ile betimlenmesi, bir çobanın hayvanları güderken vazgeçilmez gereçlerinden değneği haturlandığında, onun taşıdığı "insanlığın çobanı" sıfat ile ilişkilendirilebilir ${ }^{102}$. Ancak Güneş Tanrısı ile aynı biçimde tasvir edilen kralların böyle bir sıfatı taşıyıp taşımadıklarına dair bir bilgimiz yoktur ${ }^{103}$.

Kimi zaman LúSIPA "çoban" kimi zaman da LúSIPA.UDU "koyun çobanı"nın Güneş Tanrısı'nı tanımlayan bu sözcükler içinde kullanılmış olması dikkati çekmektedir. Bu farklı kullanım üstelik birbirine paralel olan üç metinden ikisinde karşımıza çıkar. KUB XXIV 8 II 15'de LúSIPA.UDU geçiyor iken bunun paraleli KUB XXXVI 59 I 11 'de LÚSIPA-aš olarak geçer. Üçüncü paralel metinde ilgili yer kırık olduğu için onu bilemiyoruz. Ama buradan anlaşıllyor ki LÚSIPA ve LúSIPA.UDU birbirinin yerine kullanılmaktadır. Bu duruma bir başka örnek de yukarıda değindiğimiz ${ }^{104}$ kanunların 35 . maddesinde LúSIPA yer alıyorken, hemen hemen aynı içerikteki 175 . maddede LÚSIPA.UDU geçiyor olmasıdır. Buna göre LÚSIPA ve LÚSIPA.UDU biri genel

${ }^{99}$ KUB XXIV 8 15. Bak. J.Siegelova, Appu-Marchen und Hedammu-Mythus, StBoT 14. Wiesbaden 1971, s.8-9.

${ }^{100}$ H.G.Güterbock, "Sungod or King," Aspects of Art and Iconography: Anatolia and it's Neighbours, Fs.N.Öngüç, Ed. M.Mellink ve diğ., Ankara 1993, s.225.

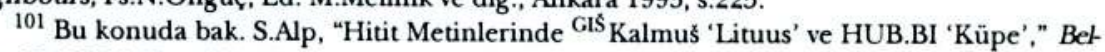
leten 12/46(1948), s.301 vd.

${ }^{102}$ Bak. Beckman, Fs. Otten, s.42-43.

${ }^{103}$ Beckman, Fs.Otten, s.43.

${ }^{104}$ Bak. s. 6 dn. 23. 
anlamda "çoban", diğeri belli bir hayvana göre "koyun çobanı" olarak belirlenmekle beraber, birbirinden farklı yerlerde kullanılmadıklarını biliyoruz. LÚSIPA.UDU ve LúSIPA.GU ${ }_{4}$ bir çok metinde ard arda geçmektedir. Bunlar şüphesiz, hayvancilığın temel geçim kaynaklarından biri olduğu Eski Anadolu'da en yaygın olarak beslenen koyun ve sığıra göre belirlenmiş çoban gruplarıdır. Koyun çobanının, genel anlamda çoban yerine kullanılmış olduğunu gösteren örnekler, küçükbaş hayvanların Hititler'in yaşadıkları coğrafyada daha yaygın olarak beslenmiş olmasının bir sonucu olarak değerlendirilebilir.

Günümüze dek ulaşan Hititçe çivi yazılı belgeler her ne kadar çok çeşitli içerikte olsalar da, bilindiği gibi Hitit toplumunun günlük yaşantsına dair geniş bilgiler vermekten uzaktur. Bu nedenle, toplumun temel geçim kaynaklarından birini oluşturan hayvancılık dolayısıyla Hitit kültüründe ağırlığı olması gerektiği halde çobanlık, çivi yazılı belgelerde sınırlı sayıda kayıtlarla karşımıza çıkar. Ancak çobanlıkla ilgili sözcük ve terimlerdeki çeşitlilik, evcil hayvanların neredeyse tümünün adını içeren bir çoban teriminin bulunuyor olması bu ağırlığın bir göstergesidir. Anlamları dolayısıyla çoban ve çobanlıkla ilgili olarak ortaya çıkan sözcük ve terimler, toplumdaki bir alt sınıftan üst düzeyde bir askeri görevliye, kırsal alanda doğrudan çobanlık yapanlardan tapınak görevlilerine, farklı toplumsal statü, nitelik ve alanlarda görülürler. Yukarıda ele aldığımız bazı terimlerin doğrudan çobanlık işi ile ilgili olmadığı halde, yani bizzat hayvanların bakımı, beslenmesi, sevk ve idaresi ile ilgili olmadığı halde çoban anlamı içeriyor olmaları, Hitit kültüründe çobanlığın edindiği yeri ve tarihsel gelişim çizgisinde uğradığı anlam değişme ve gelişmelerini göstermektedir. 
